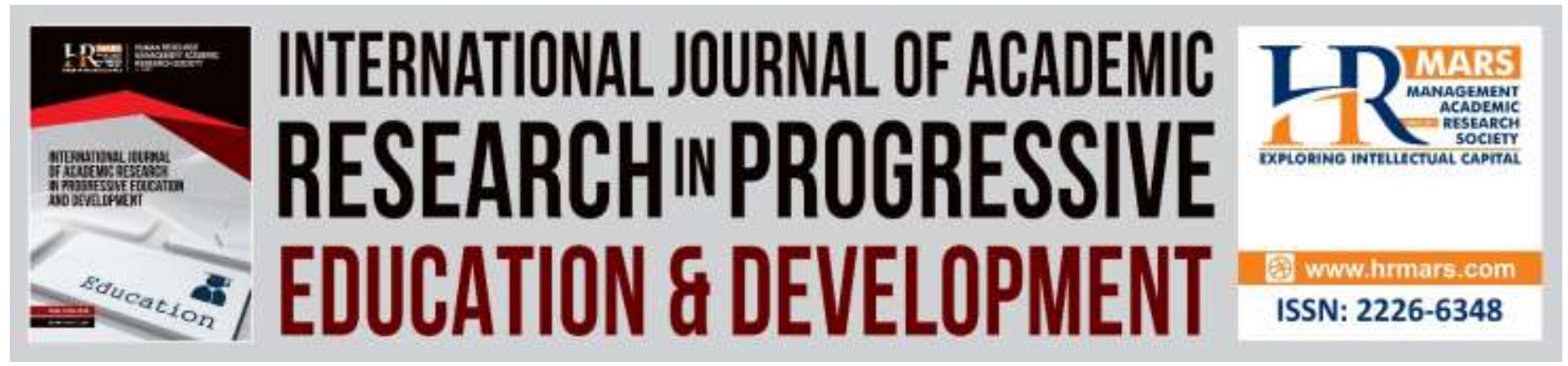

\title{
Blended Learning in Islamic Studies
}

\section{Nor Zanira Abd Manan, Hafizul Fahri Hanafi}

To Link this Article: http://dx.doi.org/10.6007/IJARPED/v9-i2/7303

DOI:10.6007/IJARPED/v9-i2/7303

Received: 26 March 2020, Revised: 30 April 2020, Accepted: 11 May 2020

Published Online: 05 June 2020

In-Text Citation: (Manan \& Hanafi, 2020)

To Cite this Article: Manan, N. Z. A., \& Hanafi, H. F. (2020). Blended Learning in Islamic Studies. International Journal of Academic Research in Progressive Education and Development, 9(2), 299-308.

Copyright: (C) 2020 The Author(s)

Published by Human Resource Management Academic Research Society (www.hrmars.com)

This article is published under the Creative Commons Attribution (CC BY 4.0) license. Anyone may reproduce, distribute, translate and create derivative works of this article (for both commercial and non-commercial purposes), subject to full attribution to the original publication and authors. The full terms of this license may be seen at: $\underline{\text { http://creativecommons.org/licences/by/4.0/legalcode }}$

\section{Vol. 9(2) 2020, Pg. 299 - 308}

Full Terms \& Conditions of access and use can be found at http://hrmars.com/index.php/pages/detail/publication-ethics 


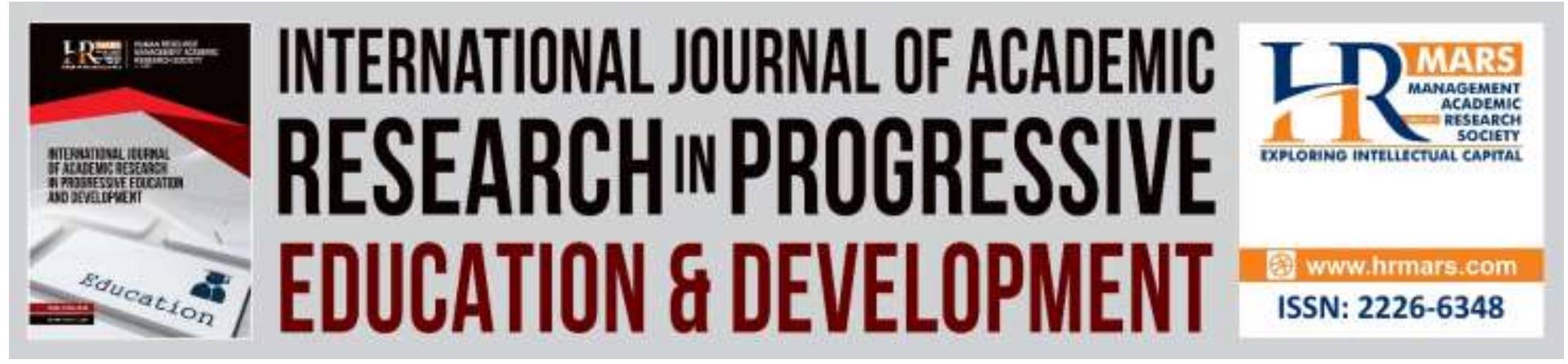

\title{
Blended Learning in Islamic Studies
}

\author{
Nor Zanira Abd Manan, Hafizul Fahri Hanafi \\ Department of Computing, Faculty of Arts, Computing and Creative Industry, Universiti \\ Pendidikan Sultan Idris, 35900 Tanjong Malim, Perak, Malaysia
}

\begin{abstract}
Islamic Studies is one of the core subjects that require to be taken by each and every Muslim student in Malaysia. Even though these subjects are considered trivial by public and deemed nonessential compared to other subjects, instead it requires high concentration and focus from the students. Each year, the increment of students that failed in this subject arise. Therefore, study shows the Blended Learning method by combining application of Google Classroom and VAK learning style in the process of teaching and learning will overcome arise matter. Technology consolidation such as Google classroom application seem suitable and compatible to the students in this new millennium. Since this Islamic Studies consisting of reading activities, memorizing and practicality the selection of VAK Learning method will provide the most suitable learning pattern to the students. The outcome of this study is expected to increase students interest and enable them to dominate the subjects.
\end{abstract}

Keywords: Islamic Studies, Blended Learning, Google Classroom, VAK learning Style.

\section{Introduction}

Blended Learning is a popular learning method used by educational institutions since the past few years. It is a conventional learning combination with online learning or computer-based learning. According to Singh (2003), Blended Learning is also defined as a combination of various media; teaching methods, activities, teaching aids and combined conventional and online learning. However, the view of Rihatul (2017) also states Blended Learning also combines MLearning (Mobile Learning) elements.

This method is also more flexible or easy to manage since it is unlimited in terms of implementation time and place for a learning session to be conduct. According to Rizkiyah (2015), the Blended Learning will be more effective whenever traditional learning that is commonly used is assisted by online learning. Information gathering and also solutions solving will be much easier to the students. According to Norasyikin and Mat Isa, (2016), there were several characteristics in the Blended Learning, which is the transition from a lecturer-centered learning to studentcentered, an increase in interaction between students and lecturers, among students, students with educational content and students with external information. 
Through this method application, apart from receiving the explanation by the teacher in the classroom, students may also access information or learning materials provided by the teacher online through Google Classroom. Hence students can discuss among themselves for completing a task or solving a problem assigned by the teacher from the previous learning session. According to Sudarman (2014), students commonly use online learning to complete group or other assignments. Teachers will play a role as a facilitator and provide space for students to gain their own learning experience.

Besides that, Blended Learning method is also one of the best effort to increase student interest during learning session in the classroom. The variation introduce by the teacher will ensure students to continue interested to the subjects that they need to learn. By considering the rapid evolving technology era of this generation nowadays experience, this method is very much compatible to implement. According to Sudarman (2014), Blended Learning method set the implementation for direct learning of as much as $50 \%$, for free learning through various interactive media at $25 \%$ and the online learning as much as $25 \%$. Based on that division, it does not represent that the teacher's role in the classrooms will be replaced by online learning or other media.

In addition, Blended Learning is a most suitable method to be implemented by teachers since the students in a class may had varies style of learning. Hence appropriate selection of learning styles that suit students will help them to learn well. Therefore, this method is also adapted to the VAK learning style, generally there are students who easily absorb learning by simply reading the text or image, some with ability to focus of listening in the class and some through the movement. This kind of method will blend well with Islamic Studies subjects which indeed apply the forms of learning such as reading, memorized, writing and doing practical such as prayer, Tawaf, slaughter and others.

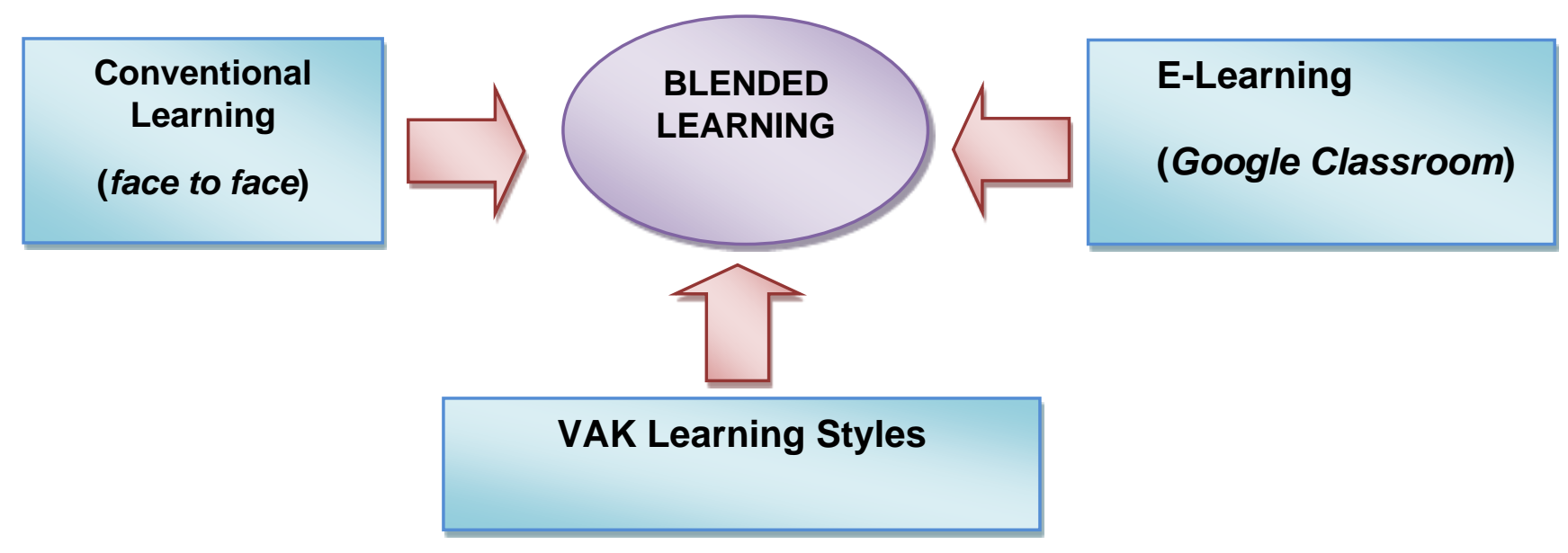

Figure 1. Diagrams of elements in Blended Learning 
Vol. 9, No. 2, 2020, E-ISSN: 2226-6348 @ 2020 HRMARS

\section{Literature Review \\ E-Learning}

E-Learning is a learning process whereby its make use of LAN's electronic network, WAN or the Internet to deliver the content, information and interaction through it and also able to facilitate its users especially teachers and students (Yusof \& Tahir, 2017). While according to Aziz and Ahmed (2016), E-learning has been one of the common methods applied in education field, either for high or public level, aside from that this method also will accelerate the learning process in an effective manner.

The main objective for E-learning implementation is to produce kind of new learning and teaching environment so that it can facilitate interaction among teachers and students. Idrus and Buntat (2016), believes that through this E-learning method, students manage to access their lesson content repeatedly manner until it can be fully understood by the student. Besides that, it is also able to eliminate shy feeling inside certain student to inquire questions.

Not to be denied in a class or lecture there is certain student with introvert personality attitude, which they would prefer to keep themselves even though they could not understand what was presented by the teacher. Those students which is categorized as Introverts choose to keep quite while in classrooms, but they actually expert in ICT, and actively involved in social media. Nursyahrurahmah (2017), those with an introvert personality are more difficult to engage social interaction and choose to communicate personally and undergo every activity on their own or with close friends only.

In addition, it will also provide an advantage to students who have a difficulty while communicating in classrooms, E-Learning will facilitate space and more flexible time for student to learn. It will reduce students time to copy notes, furthermore they can even comprehend more if the explanation of the teachers supported by the aid of visual, audio and video. Yusof and Tahir (2017) agreed that learning process can be created in a conducive and pleasant environment if information technology applied incorporate voice techniques, sounds, video pictures and text.

Writing by Amiruddin et al., (2014) reveals that the use of several E-Learning applications that are very suitable for the teachers such as; Quizlet.com, GoAnime.Com and Hot Potatoes. The applications mentioned above are suitable to be adapt into the learning dimensions and space as they can make the learning session more attractive and interactive. Meanwhile, study conducted by Aziz and Ahmed (2016) to 100 students IPG, Ipoh found out a sample agree with the implementation of E-Learning. The study also concluded that the use of E-Learning is dependent on the level of motivation and interest of the individual to learn its usage or not. This is because of the those who had a high level of interest will be fully concentrated onward the technology that had been used.

While the researchers of Sarizun and Zuraidah (2017) have found that most of the samples are aware of the necessity of E-Learning as a learning style nowadays that aligns with the development of technology. The findings also show that, majority of the sample acknowledge that E-Learning provides many benefits and helps in their learning. However, due to lack of 
Vol. 9, No. 2, 2020, E-ISSN: 2226-6348@ 2020 HRMARS

motivation and knowledge to apply E-Learning makes the usage among them is moderate. The finding was opposed to the study findings by Subramaniam et al., (2013), which $100 \%$ of the course agreed to use E-Learning in their courses and will always strive to obtain learning materials.

\section{Google Classroom}

Google Classroom is an application developed by the United States multinational technology company, which focuses on educational field since 2014. It is widely used by the school and the university. Google Classroom can be used as a virtual learning environment, as well as on-line learning, and also capable to be a mobile learning because the application can be installed on a mobile device such as smartphones, tablets etc.

Since from 2014 of its establishment, Google Classroom was introduced in education field and various forms of research has been carried out on it. According to Shaharanee et al., (2016) that Google Classroom has a high potential under educational field as it combines unique functions such as pedagogical, social and technology. The application enables teachers to draft assignment or exercise instantly, response efficiently, and also easily communicate with students. These research findings proof that the students were very much satisfied with Google Classroom and it was a very effective teaching aid medium.

In other study by Bhat et al., (2018), quoted that the teacher may use Google Classroom for any subject for the entire students in the classroom. Besides that, it also involves many teachers in a single Google Classroom environment as well. The teacher can be equally instrumental in helping to increase students for better understanding and also to help their fellow teachers. This kind of situation visualize a good overview of the cooperation between teachers in order to produce excellent student.

Subsequently, study by Gunawan and Geima (2017) found out students that using Google Classroom application will felt that they not been left behind but at the same time felt assisted in order to understand the learning. There are also feedback from students mentioning that by using this application, time and energy consume will be reduce compare to the conventional method that required them to copy notes given by the teacher. This kind of environment create an effective learning session and able to attract students interest.

Meanwhile, study conducted by Beaumont (2018) evaluates from the teacher's perspective finds that Google Classroom is a convenience way to create assignment in classroom, and it's easier to manage student's involvement. This application is also an effective platform used by teachers for a various educational purpose and can improve student involvement through discussion sessions according to topics or assignments in a surprising order. Besides that, this application also will enable good learning management platform for the teachers and information sharing through the apps (Gunawan and Geima, 2017). 
Through the various applications provided by this Google Classroom, teachers should be more creative in order to attract students since students nowadays are "cyber-age children". Ever since childhood most of them have been exposed to the usage of tablets and smartphones by their parent to avoid disturbance while doing task. Thus, the teacher must play a role wisely to ensure the students to fall in love with the subjects being taught. In addition to this application of Google Classroom, students will improve their cognitive skills by themselves (Al-Maroof \& AlEmran, 2018).

As an effort to use this Google Classroom as a teaching aid, teachers must have an interesting personality and need to encourage students to use it. Even the teacher needs to be well verse of its usage, since it can create a fun learning environment and indirectly improve the professionalism of a teacher (Rulbani et al., 2017). This will make the learning session run smoothly and effectively if the students are interested in learning (Inggriyani et al., 2019).

\section{VAK learning Styles}

VAK learning styles have been pioneered by Fernald, Keller, Orton, Gillingham, Stillman and Montessori in 1920 and its combine three main elements of learning that is visual, auditory and kinesthetic. According to Ulia and Sari (2018), this style of multi-sensory learning can encourage the learning development of the student and also capable to combine students ability to overcome their weakness.

Researchers have chosen the VAK learning style in this study since it is perfectly suitable for Islamic Studies subjects. There are practical, images and Quran's verses that can be memorized by the students throughout this style. Latifah et al., (2019) stated that school students generally able to learn better when its involving vision, hearing and gestures.

Visual learning refers to the effective learning process of learners through concepts, drawings or through visualize activities. Students of this category are said to be able to learn better and memorize when looking at text written on a white board or display text on a computer. Besides, this student capable to memorize well when seeing pictures, images or movies.

Students who tend to this visualize will always prefer to rewrite whatever they learn in the form of a note by using multi-colour pen for highlighting the facts. According to Musliza and Mokmin (2015), students who learn through this visual method always write instructions and explanations that are given orally to be remembered. Teachers can use teaching materials such as picture cards, web pages or maps or mind maps to enhance their understanding in learning.

The auditory learning method refers to a learning style that is more inclined and sensitive to auditory sensory. Auditory students are referred to those who able to learn well by hearing the spoken words and oral instruction. They will hear the lecturing voice recording before reading the notes given. They can remember the explanation through high volume readings or move the lips when reading especially when learning something new. The student can enhance 
their memory by hearing the voice recording, explaining and discussing among students and teachers.

According to Mok (2001), mentioning auditory students prefer making and reading of their own notes, however they are quite skeptical to participate in group activities. They prefer the story telling technique as a learning tool. In addition, these types of students would like to speak alone during reading and studying. Equipments such as recording tapes, radios and computer will benefit most to auditory type students. The recommended activity for Auditory students is to discuss, interview, lectures, recordings and games. Teachers can mastering the key element in students learning sessions such as using music, and videos or films through oral performances in the curriculum implementation.

Kinesthetic type students refer those who learn throughout the body movement and psychomotor skills. These students will explore new exercise as a result of their vision. They will also write special notes and teacher notes. They are tend to answer questions in writing form. Kinesthetic students are also referred to those who learn well through experience and participation in physical activities in classroom. They can remember well when involving activities by using hand movement efficiency. Computer usage, games and exploring activities involving vocabulary will increase the effectiveness of kinesthetic type student learning.

\section{Methodology}

This study will use quantitative method and descriptive analysis. Data will be collect using the findings of the questionnaires instrument. The respondents in this study will consist $n=36$ form four students from smk setia alam.

\section{Discussion}

Each student has different learning styles and learning skills. Teachers need to understand the learning style practiced by each student and need to know the appropriate learning style to themselves. Therefore, teachers can provide suitable teaching methods that can increase their interest in the subjects and motivate them in learning. Not all learning styles practiced by students are correct. Teachers can help students to find the suits learning style that can help them to achieve an effective learning process. It also can help students to become active and successful in their learning.

Although this VAK learning style is comprehensive for different kinds of learning styles, but to provide a variety of tools for all students is quite impossible to implement. This is because a class will contain more than 30 students and teachers only have a limited time for every learning session. The function of this learning style may also vary according to the time, environment, learning issues as well as some mental, physical and psychological characteristics of students. Student may have one or more specific learning styles. In fact, these learning styles may also be dynamic, which can be vary. 
Hence, the blended learning which incorporates two methods of learning which is traditional and online will be the best learning methods to attract students. This is because blended learning also applied the technology, which is very favourite to students in this century. Blended learning also maintains the traditional methods that enable students to obtain clear explanations from the teachers. This method also combine VAK learning styles through the methods of explanation, reading and memorization and practical such as prayer, Athan and others.

\section{Conclusion}

The ability to master Islamic Studies subjects is dependent on the selection of learning styles appropriate to the student's acceptance level. Various activities can be implemented in the VAK learning style appropriate to the student condition. In addition, the use of technologies such as Google Classroom is also helping to attract students to fall in love with these subjects and thus increasing the performance of these subjects especially in the SPM examination.

\section{Acknowledgement}

We would like to thank the people involved in making this article published. Do not forget the faculty and university to trust us. Finally, thanks to our family and friends who have supported us all this time.

\section{Corresponding Author}

Nor Zanira Abd Manan

Faculty of Arts, Computing And Creative Industry

University Pendidikan Sultan Idris, Malaysia

Email: zaniramanan@gmail.com

\section{References}

Aziz, A. N. A., \& Ahmed, M, T. (2016). E-Pembelajaran dalam pengajaran dan pembelajaran Bahasa Melayu di IPG Kampus Ipoh. Jurnal Penyelidikan Dedikasi, 11, 116-130.

Al-Maroof, R., \& Al-Emran, M. (2018). Students Acceptance of Google Classroom: An Exploratory Study using PLS-SEM Approach. International Journal of Emerging Technologies in Learning, 13(6), 112-123.

Amiruddin, A. Z., Ghani, A. K., Hassan, A. T., Rahman, A. N., \& Bakar, A. M. S. (2014). Penggunaan Aplikasi Atas Talian Dalam Proses Pengajaran Dan Pembelajaran Bahasa Ketiga. Prosiding Seminar Antarabangsa Kelestarian.

Beaumont, K. (2018). Google Classroom: An online learning environment to support Blended Learning. Journal of Learning and Teaching, 11(2), $1-6$.

Bhat, S., Raju, R., Bikramjit, A., \& D’souza, R. (2018). Leveraging E-Learning through Google Classroom: A Usability Study, Journal of Engineering Education Transformations, 31(3), 12-18.

Gunawan, F, I., \& Geima, S. (2017). Pengembangan Kelas Virtual Dengan Google Classroom Dalam Keterampilan Pemecahan Masalah (Problem Solving) topik Vektor Pada Siswa SMK Untuk Mendukung Pembelajaran. Prosiding Seminar Nasional Etnomatnesia. 
Idrus, W., \& Buntat, Y. (2016). Aplikasi E-Learning Dalam Pengajaran \& Pembelajaran di Malaysia, Fakulti Pendidikan : Universiti Teknologi Malaysia. Retrieved on 20 Mei 2018, from https://www.researchgate.net/publication/242693034_APLIKASI_'E-

LEARNING_'DALAM_PENGAJARAN_PEMBELAJARAN_DI_SEKOLAH-

SEKOLAH_MALAYSIA_isu_dan_cadangan_perlaksanaannya

Inggriyani, F., Hamdani, A. R., \& Dahlan, T. (2019). Minat Belajar Mahasiswa dengan Menggunakan Blended Learning melalui Google Classroom pada Pembelajaran Konsep Dasar Bahasa Indonesia SD. Jurnal IImu Pendidikan, Keguruan, dan Pembelajaran, 3(1), 28-35.

Lathifah, W., Nurochmah, A., \& Sutisnawati, A. (2019). Pengaruh Model Pembelajaran VisualAuditory-Kinesthetic (Vak) Terhadap Kemampuan Berpikir Kritis Di Kelas Tinggi Sekolah Dasar. Caruban : Jurnal IImiah Pendidikan Dasar, 2(2), 102-114.

Shaharanee, M. I. N., Jamil, M. J., \& Rodzi, M. S. S. (2016). The Application of Google Classroom as a Tool for Teaching and Learning. Journal of Telecommunication, Electronic and Computer Engineering, 8(10), 5-8.

Yusof, M. M. N, \& Tahir, Z. (2017). Kepentingan Penggunaan Media Sosial Teknologi Maklumat Dalam pendidikan IPTA. Journal of Sains Sosial and Humanitie, 12(3), 1-10

Mok, S. S. (2001). Psikologi Pendidikan Untuk Kursus Diploma Perguruan Semester 1 dan 2. Kuala Lumpur: Kumpulan Budiman Sdn. Bhd.

Musliza, N. \& Mokmin, B. (2015). Pembelajaran VAK (Visual, Auditori Dan Kinestetik). Seminar Wahyu Asas Tamadun.

Norasyikin, O. \& Mat Isa, H. (2016). Hubungan Kesediaan Pelajar Mengikuti Pembelajaran Berasaskan Blended Learning Berdasarkan Jantina dan Program. Jurnal Kurikulum \& Pengajaran Asia Pasifik, 4(2), 1-9.

Nursyahrurahmah, N. (2017). Hubungan Antara Keperibadian Introvert dan Kelekatan Teman Sebaya Dengan Kesepian Remaja. Jurnal Ecopsy, 4(2), 113-116.

Rihatul, L., (2017). Pengaruh Pembelajaran Bauran (Blended Learning) Terhadap Motivasi Siswa Pasa Materi Relasi dan Fungsi. Jurnal Ilmiah Pendidikan Matematika, 2(1), 36-42.

Rizkiyah, A. (2015). Penerapan Blended Learning untuk Meningkatkan Hasil Belajar Siswa pada Mata Pelajaran Ilmu Bangunan di Kelas X TGB SMK Negeri 7 Surabaya. Jurnal Kajian Pendidikan Teknik Bangunan, 1(1), 40-49.

Rulbani, S., Mat Isa, H., \& Khadijah, A. R. (2017). Penggunaan ICT dalam Pengajaran dan Pembelajaran Pensyarah Pendidikan Islam di Politeknik Zon Selatan. Tinta Artikulasi Membina Ummah, 3(1), 29-41.

Sarizun \& Zuraidah. (2017). Kesedaran e-Pembelajaran Dalam Kalangan Pelajar Di Politeknik Sultan Salahhuddin Abdul Aziz Shah. e-Proceeding National Innovation and Invention Competition Through Exhibition.

Singh, H. (2003). Building effective Blended Learning programs. Educational Technology, 43(6), 51-54.

Subramanian, S.T.S., Nordin, N., \& Krishnan, M. (2013). E-Content Development in Engineering Courses: Students Needs and Readiness, International Journal of Business and Social Science, 4 (6),282- 288. 
INTERNATIONAL JOURNAL OF ACADEMIC RESEARCH IN PROGRESSIVE EDUCATION AND

DEVELOPMENT

Vol. 9, No. 2, 2020, E-ISSN: 2226-6348 @ 2020 HRMARS

Sudarman, S. (2014). Pengaruh Strategi Pembelajaran Blended Learning Terhadap Perolehan Belajar Konsep Dan Prosedur Pada Mahasiswa Yang Memiliki Self-Regulated Learning Berbeda. Jurnal Pendidikan dan Pembelajaran, 21(1), 107 - 117.

Ulia, N., \& Sari, Y. (2018). Pembelajaran Visual, Auditory dan Kinestetik Terhadap Keaktifan dan Pemahaman Konsep Matematika Siswa Sekolah Dasar. Al Ibtida: Jurnal Pendidikan Guru MI, 5(2), 175. 